\title{
APLIKASI SAINS PADAANAK USIA DINI DALAM KELUARGA UNTUK MENGHADAPI ABAD 21
}

\author{
Nana Nana ${ }^{1}$ \\ ${ }^{1}$ Universitas Siliwangi, Tasikmalaya, 46115 \\ Email Korespodensi:nana@unsil.ac.id
}

Diajukan: 20 January 2020; Diterima: 25 February 2020; Diterbitkan: 30 April 2020

\begin{abstract}
Abstrak: Penelitian ini bertujuan untuk mendeskripsikan aplikasi sains pada anak usia dini dalam keluarga untuk menghadapi abad 21. Penelitian ini menggunakan metode penelitian Deskriptif kualitatif yang di arahkan pada field research jenis. Jenis data yang digunakan adalah data-data yang diperoleh bersumber dari observasi, pengumpulan data lapangan, wawancara, dan dokumentasi. Hasil penelitian menunjukkan hasil yang cukup baik bahwa 2\% partisipan tidak pernah mengaplikasikan sains, $12 \%$ jarang, 39\% netral, 37\% sering, dan $10 \%$ sangat sering. Hasil ini akan ditindaklanjuti dengan workshop, program parenting, pembatasan penggunaan telepon selular dan program literasi. Hasil yang dicapai ke nantinya akan mendorong orang tua untuk lebih memahami pengaplikasian sains dan pola asuh anak yang baik dan benar. Selain itu, anak akan ditumbuhkembangkan minat membacanya, dan didorong untuk semakin imajinatif dan kreatif.
\end{abstract}

Kata Kunci: Sains, Pendidikan Keluarga, Abad 21

Abstract: This study aims to describe the application of science in early childhood in the family to face the 21st century. This study uses descriptive qualitative research methods that are directed at field research types. The type of data used is data obtained from observations, field data collection, interviews, and documentation. The results of the study showed a fairly good result that $2 \%$ of participants never applied science, $12 \%$ rarely, 39\% neutral, $37 \%$ often, and $10 \%$ very often. These results will be followed up with workshops, parenting programs, restrictions on the use of cellular phones and literacy programs. The results achieved in the future will encourage parents to better understand the application of science and good and correct parenting. In addition, children will develop an interest in reading, and are encouraged to be more imaginative and creative.

Keywords: Science, Family Education, 21 st Century

\section{Pendahuluan}

Pembelajaran sains dalam Pendidikan Anak Usia Dini (PAUD) merupakan suatu rangkaian kegiatan belajar untuk menstimulus anak dalam mengeksplorasi lingkungan sekitar dan merefleksikan hasil pengamatan dan penemuannya. Pembelajaran sains pada anak usia dini mencakup tentang pembelajaran mengenai diri sendiri, alam sekitar, dan fenomena alam. Hakikat pembelajaran sains yaitu memberikan pengalaman yang menantang kepada anak, sehingga anak mempunyai rasa ingin tahu tentang berbagai macam objek fisik, alam sekitar, atau kejadiankejadian yang ada di lingkungan anak.

Lingkungan anak mencakup keluarga, sekolah, dan masyarakat. Namun, dalam penelitian ini difokuskan pada lingkungan keluarga, yaitu keterlibatan orang tua dalam mengajarkan sains pada anak usia dini. Keterlibatan orang tua merupakan aspek penting dalam sebuah pendidikan terutama dalam Pendidikan Anak Usia Dini (PAUD). Hal tersebut karena orang tua merupakan pendidik pertama anak di rumah dan orang yang pertama kali berinteraksi dengan anak. Keterlibatan orang tua dalam pendidikan anak dapat berpengaruh positif atau sebaliknya, tergantung pada kemampuan orang tua untuk memahami makna, bentuk dan tujuan keterlibatan itu sendiri.

Keterlibatan orang tua dalam pembelajaran sains pada anak usia dini yaitu dengan mengoptimalkan panca indra anak. Melalui panca indra tersebut, anak dilatih untuk melihat, meraba, membau, mendengar, dan merasakan apa yang terjadi di lingkungan sekitar. Dengan mengoptimalkan panca indra, maka akan menstimulus anak untuk memiliki enam keterampilan dasar sains, yaitu pengamatan (observation), mengomunikasikan (communication), pengklasifikasian 
(classification), pengukuran (measurement), penyimpulan (inference), dan peramalan (prediction). Keenam keterampilan ini sangat penting dimiliki oleh anak usia dini, karena sebagai modal berpikir lanjut untuk menjawab berbagai tantangan di jenjang pendidikan yang lebih lanjut. Hal ini menjadi salah satu tuntutan dalam menghadapi abad 21, dimana anak harus memiliki kecakapan abad 21 yang meliputi critical thinking and problem solving; creativity and innovation; communication; dan collaboration. Pentingnya penguasaan kecakapan abad 21, anak usia dini perlu mendapat keterampilan dasar sains guna menyiapkan generasi yang memiliki rasa percaya diri dan motivasi untuk mengembangkan diri secara optimal sehingga mampu bersaing secara global.

Mengingat masa usia dini adalah periode emas yang merupakan periode kritis bagi anak, dimana perkembangan yang diperoleh pada periode ini sangat berpengaruh terhadap perkembangan periode berikutnya hingga masa dewasa. Sementara masa emas ini hanya datang sekali, sehingga apabila terlewat berarti habislah peluangnya. Untuk itu pendidikan anak usia dini dalam bentuk pemberian stimulus dari lingkungan terdekat sangat diperlukan untuk mengoptimalkan kemampuan sains pada anak usia dini.

\section{Metode Penelitian}

Penelitian ini menggunakan metode penelitian deskriptif kualitatif yang mengarah ke field research. Teknik pengumpulan data yang digunakan adalah observasi, wawancara, dan dokumentasi. Instrumen penelitian yang digunakan adalah kuesioner berdasarkan pengukuran skala likert. Partisipan penelitian ini berjumlah 50 orang tua dari 5 sekolah, diantaranya RA Generasi Rabbani yang terletak di Kelurahan Sindangrasa Kecamatan Ciamis, RA Al-Mu'minin yang terletak di Kelurahan Sindangrasa Kecamatan Ciamis, PAUD Kasih Ibu yang terletak di Kelurahan Sindangrasa Kecamatan Ciamis, PAUD Bintang Al-Iman yang terletak di Desa Imbanagara Raya Kecamatan Ciamis, dan RA Al-Fadiliyyah. Partisipan penelitian ini dipilih dengan menggunakan teknik systemic random sampling. Penelitian ini dilaksanakan di Kabupaten Ciamis dengan menggunakan.

\section{Hasil Penelitian dan Pembahasan}

\section{Hasil Observasi Aplikasi Sains pada Anak Usia Dini dalam Keluarga}

Berdasarkan pernyataan dalam kuesioner yang diberikan, orang tua murid memberikan respon yang berbeda satu sama lain, seperti yang disajikan dalam diagram di bawah ini:

\section{Pengaplikasian Sains} dalam Keluarga

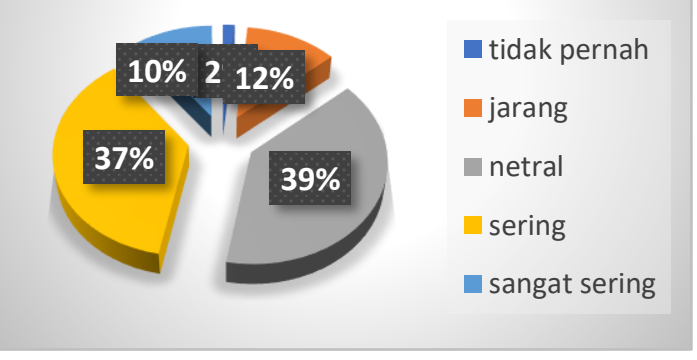

Diagram 3.1. Hasil Kuesioner Pengaplikasian Sains pada Anak Usia Dini dalam Keluarga

Diagram 3.1 di atas menunjukkan bahwa orang tua murid cenderung netral dalam mengaplikasikan sains di lingkungan keluarga. Untuk mengetahui lebih jelas, berikut adalah rincian setiap pernyataan yang diberikan:

Dalam pernyataan pertama, orang tua mengenalkan bagian-bagian anggota tubuh pada anak. Jawaban yang diberikan partisipan adalah sebanyak 17 orang netral 22 orang sering dan 11 orang sangat sering. Berdasarkan jawaban tersebut pernyataan pertama masuk dalam kategori kuat dengan hasil 77,6\% $\left(\frac{(17 \times 3)+(22 \times 4)+(11 \times 5)}{250} \times 100 \%=77,6 \%\right)$.

Dalam pernyataan kedua, orang tua mengajarkan kegunaan bagian-bagian anggota tubuh kepada anak. Berdasarkan jawaban yang diberikan partisipan, didapat jawaban jarang sebanyak 1, netral sebanyak 18 , sering sebanyak 23 orang, dan sangat sering sebanyak 8 orang. Berdasarkan hasil tersebut, pernyataan kedua juga masuk dalam kategori kuat dengan hasil $75,2 \% \quad\left(\frac{(1 \times 2)+(18 \times 3)+(23 \times 4)+(8 \times 5)}{250} \times\right.$ $100 \%=75,2 \%)$.

Dalam pernyataan ketiga, orang tua mengajarkan kepada anak tentang pentingnya menjaga anggota tubuh secara ilmiah. Berdasarkan hasil kuesioner yang diberikan, 
orang tua menjawab tidak pernah sebanyak 1 orang, jarang sebanyak 8 orang, netral sebanyak 20 orang, sering sebanyak 16 orang, dan sangat sering sebanyak 5 orang. Berdasarkan skor di atas, pernyataan ketiga masuk dalam kategori kuat dengan hasil 66,4\% $\left(\frac{(1 \times 1)+(8 \times 2)+(20 \times 3)+(16 \times 4)+(5 \times 5)}{250} \times 100 \%=\right.$ $66,4 \%)$.

Dalam pernyataan keempat, orang tua mengenalkan tanaman atau hewan yang ada di sekitar rumah kepada anak. Berdasarkan jawaban yang diberikan, didapatkan jawaban jarang sebanyak 10 , netral sebanyak 17 , sering sebanyak 20, dan sangat sering sebanyak 3 . Berdasarkan skor di atas, pernyataan keempat ini masuk dalam kategori cukup dengan hasil $66,4 \%\left(\frac{(10 \times 2)+(17 \times 3)+(20 \times 4)+(3 \times 5)}{250} \times 100 \%=\right.$ $66,4 \%)$.

Dalam pernyataan kelima, orang tua mengajarkan kepada anak cara memelihara tanaman atau hewan yang ada di sekitar rumah. Berdasarkan hasil survey, orang tua menjawab tidak pernah sebanyak 4 orang, jarang sebanyak 19 orang, netral sebanyak 20 orang, dan sering 7 orang. Berdasarkan hasil tersebut, pernyataan kelima masuk dalam kategori cukup dengan hasil $52 \% \quad\left(\frac{(4 \times 2)+(19 \times 3)+(20 \times 4)}{250} \times\right.$ $100 \%=52 \%)$.

Dalam pernyataan keenam, orang tua mengajarkan kepada anak pentingnya memelihara tanaman atau hewan yang ada di sekitar rumah. Berdasarkan hasil survey, orang tua menjawab tidak pernah sebanyak 5 orang, jarang sebanyak 22 orang, netral sebanyak 18 orang, dan sering 5 orang. Berdasarkan hasil tersebut, pernyataan keenam masuk dalam kategori cukup dengan hasil 49,2\% $\left(\frac{(5 \times 1)+(22 \times 2)+(18 \times 3)+(5 \times 4)}{250} \times 100 \%=\right.$

$49,2 \%)$.

Dalam pernyataan ketujuh, orang tua mengenalkan sistem tata surya secara sederhana kepada anak. Berdasarkan hasil survey, partisipan menjawab tidak pernah sebanyak 10 orang, jarang sebanyak 14 orang, netral sebanyak 22 orang, dan sering 4 orang. Berdasarkan skor di atas, pernyataan ketujuh masuk dalam kategori cukup dengan hasil $48 \%$ $\left(\frac{(10 \times 1)+(14 \times 2)+(22 \times 3)+(3 \times 4)}{250} \times 100 \%=\right.$ $48 \%)$.
Dalam pernyataan kedelapan, orang tua mengenalkan benda-benda yang ada di lingkungan sekitar kepada anak. Berdasarkan jawaban yang diberikan oleh partisipan, terdapat jawaban tidak pernah sebanyak 2, jarang sebanyak 5, netral sebanyak 29, sering 13, dan sangat sering sebanyak 1 . Berdasarkan hasil tersebut, pernyataan kedelapan masuk dalam kategori kuat dengan hasil 62,4\% $\left(\frac{(2 \times 1)+(5 \times 2)+(29 \times 3)+(13 \times 4)+(1 \times 1)}{250} \times 100 \%=\right.$ $62,4 \%)$.

Dalam pernyataan kesembilan, orang tua mengajarkan bentuk-bentuk benda yang ada di lingkungan sekitar kepada anak berdasarkan hasil survey, partisipan yang menjawab tidak pernah sebanyak 1 orang, jarang sebanyak 9 orang, netral sebanyak 23 orang, sering 16 orang, dan sangat sering sebanyak 1 orang. Berdasarkan jawaban tersebut, pernyataan kesembilan masuk dalam kategori kuat dengan hasil $62,8 \%$

$\left(\frac{(1 \times 1)+(9 \times 2)+(23 \times 3)+(16 \times 4)+(1 \times 1)}{250} \times 100 \%=\right.$ $62,8 \%)$.

Dalam pernyataan kesepuluh, orang tua mengajak anak untuk pergi ke taman, kebun atau sawah. Berdasarkan hasil survey, partisipan yang menjawab tidak pernah sebanyak 1 orang, jarang sebanyak 7 orang, netral sebanyak 21 orang, sering 18 orang, dan sangat sering sebanyak 3 orang. Berdasarkan jawaban tersebut, pernyataan kesepuluh masuk dalam kategori kuat dengan hasil $66 \%$ $\left(\frac{(1 \times 1)+(7 \times 2)+(21 \times 3)+(18 \times 4)+(3 \times 1)}{250} \times 100 \%=\right.$ $66 \%)$

Hasil penelitian di atas menunjukkan hasil yang cukup baik, meskipun perlu peningkatan. Oleh karena itu, penelitian ini harus ditindaklanjuti kedepannya oleh masingmasing orang tua. Orang tua harus meningkatkan kerjasama dengan guru dan juga instansi terkait lainnya seperti petugas kesehatan maupun ahli psikologi anak baik dengan mengikuti workshop atau parenting yang berkenaan dengan cara dan kiat memberikan pengasuhan dan pola asuh yang baik dan benar. Orang tua juga harus membatasi penggunaan telepon seluler pada anak meskipun yang diakses adalah film film anak karena efek radiasinya akan berdampak negatif pada proses perkembangan otak dan 
kesehatan anak. Selain itu, orang tua juga bisa meningkatkan program literasi dalam keluarga baik secara langsung dengan mengajak anak membaca sebuah buku cerita, maupun secara tidak langsung dengan mengajak anak mengunjungi Perpustakaan Daerah (PerpusDa) Kabupaten Ciamis. Perpustakaan Daerah (PerpusDa) Kabupaten Ciamis sejak dulu sudah menyediakan fasilitas ruang perpustakaan anak yang nyaman dan menyenangkan dilengkapi dengan aneka alat permainan edukatif, buku buku anak yang lucu dan menarik untuk disimak, dan juga berbagai alat untuk mengembangkan imajinasi anak bahkan saat ini telah dilengkapi pula dengan Ruangan sejenis Planetarium yang didisain sedemikian rupa, sehingga anak usia dini akan mampu mengenal dan memahami keberadan dan sistem tata surya serta lingkungan alam sekitarnya melalui literasi. Semakin sering orang tua mengajak anak untuk membaca dan mengunjungi perpusda maka akan semakin tinggi minat anak untuk membaca, berimajinasi,danberkarya membuat sesuatu sebagai usaha mewujudkan imajinasinya.

\section{Hasil yang dicapai}

Setelah dilakukan tindak lanjut, penelitian ini akan menunjukkan hasil yang lebih baik dari sekarang. Hal ini dikarenakan oleh keterlibatan orang tua dalam workshop, program parenting, pembatasan penggunaan telepon seluler, dan program literasi keluarga. Kegiatan ini akan mendorong orang tua untuk lebih memahami pengaplikasian sains dan pola asuh anak yang baik dan benar. Selain itu, anak akan ditumbuhkembangkan minat membacanya, dan didorong untuk semakin imajinatif dan kreatif.

\section{Rencana Tahapan Berikutnya}

Berdasarkan hasil penelitian, rencana
tahapan penelitian berikutnya yaitu
mengadakan sosialisasi kepada Dinas
Pendidikan untuk mengusulkan suatu kebijakan
yang berkenaan dengan peningkatan dan
pengembangan sarana dan prasarana literasi.
Sehingga dengan meningkatnya
pengembangan sarana dan prasarana literasi
diharapkan orang tua mudah memberikan
pembelajaran sains sekaligus mengaplikasikan

pembelajaran sains pada anak usia dini di lingkungan keluarganya dalam menghadapi abad 21.

\section{Kesimpulan}

Pembelajaran sains dalam Pendidikan Anak Usia Dini (PAUD) sangat penting untuk mengenal diri sendiri, alam sekitar, dan fenomena alam yang berada di lingkungan sekitarnya. Lingkungan keluarga menjadi fokus dalam penelitian ini karena orang tua merupakan pendidik pertama anak di rumah dan orang yang pertama kali berinteraksi dengan anak. Keterlibatan orang tua dalam pendidikan anak dapat berpengaruh positif atau sebaliknya, tergantung pada kemampuan orang tua untuk memahami makna, bentuk dan tujuan keterlibatan itu sendiri.

Dengan tercapainya tujuan tersebut maka kita dapat mengetahui tentang pembelajaran sains pada anak usia dini di keluarga dalam menghadapi abad 21. Selain itu kita pun akan mengetahui tentang aplikasi pembelajaran sains pada anak usia dini di keluarga dalam menghadapi abad 21.

\section{Daftar Pustaka}

Diadha, R. (2015). Keterlibatan Orang Tua dalam Pendidikan Anak Usia Dini di Taman KanakKanak. Jurnal Ilmu Pendidikan dan Pengajaran.

Ferara, M.M., \& Ferara, P.J. (2005). Parents as partners: Raising awareness as a teacher preparation program. The Clearing House, $79(2), 77-82$.

M.B.A, Riduwan (2012). Pengantar Statistik Sosial. Bandung: Alfabeta

Morrison, G. S. (1988). Education and development of infants, todlers and preschoolers. USA: Scott, Foresman and Company.

Prasetyo, S. (2016). Implementasi Pembelajaran Sains untuk Anak Usia Dini dalam Menghadapi Masyarakat Ekonomi ASEAN (MEA). Literasi, Volume VII.

Sugiyarti, L., Arif, A., \& Mursalin. (2018). Pembelajaran Abad 21 di SD. Prosiding Seminar dan Diskusi Nasional Pendidikan Dasar. Jakarta: Universitas Negeri Jakarta.

Undang-Undang Nomor 20 Tahun 2003 tentang Sistem Pendidikan Nasional Pasal 7, Ayat 1.

Yusuf, S. (2011). Psikologi Perkembangan Anak dan Remaja. Bandung: PT. Remaja Rosdakarya 